\title{
鉄不動態皮膜内層のカンード還元機 構*
}

\author{
紀平 寛***, 水流 徹**, 春山志郎**
}

\section{The Mechanism of Cathodic Reduction of the Inner Layer of the Passive Film on Iron*}

\author{
Hiroshi KIHIRA***, Tooru TSURU** and Shiro HARUYAMA**
}

\begin{abstract}
Study on the cathodic reduction of passive films formed on iron in a sodium borate-boric acid buffer solution of $\mathrm{pH} 8.39$ showed that the rate of cathodic reduction of the magnetite $\left(\mathrm{Fe}_{3} \mathrm{O}_{4}\right)$ layer of the passive film was affected by stirring, solution $\mathrm{pH}$ and cathodic current density. For analytical covenience the cathodic reduction of $\mathrm{Fe}_{3} \mathrm{O}_{4}$ was divided into two partial reactions; reductive dissolution to ferrous ion and reduction to metallic iron. When current density or $\mathrm{pH}$ is high, the reaction rate of the former is determined by a saturated layer of ferrous ion adjacent to the electrode surface, and residual cathodic current is consumed by the latter reacton. The effect of stirring, $\mathrm{pH}$, and cathodic current density on the ratio of the two partial reactions, which depends upon the saturation of ferrous ion on the electrode surface, was also analyzed.
\end{abstract}

\section{1 緒言}

鉄の不動热化現象は，鉄表面に形成される厚さ30 $50 \mathrm{~A}$ 程度の酸化皮膜が鉄の活性溶解を阻止寸るために おこる.この酸化皮膜がいわゆる鉄不動態皮膜である. 純鉄の不動態皮膜構造は，主としてカッード還元法をも とにして解析がなされているが，いまだ統一した見解に は到達していない. Nagayama, Cohen ${ }^{1,2)}$ は, 純鉄のア ノード酸化，カソード還元に拉けるクロノポテンシォメ トリーを中心とした電気化学的測定, 化学分析および電 子線回折の結果から, 鉄不動態皮膜外層に $\gamma-\mathrm{Fe}_{2} \mathrm{O}_{3}$, 内層に $\mathrm{Fe}_{3} \mathrm{O}_{4}$ の 2 層構造をとるとしている。一方，估 藤ら ${ }^{3 \sim 5)}$ は主としてエリプソメトリ一の結果から外側に ほぼ $\mathrm{Fe}(\mathrm{OH})_{3}$ の組成で, 表わされる含水酸化鉄層, 内 側にはほぼ無水の $r-\mathrm{Fe}_{2} \mathrm{O}_{3}$ 層とい5, ともに 3 価の鉄 酸化物層からなる 2 層構造を提唱している.酸化物の組 成および各層の機能において両者の主張は大きく異なっ て抢り，前者の場合は皮膜外層が，後者の場合注皮膜内 層が，鉄の不動態化現象に大きな役割りをはたすとして いるが， 2 層構造をとるといら点では共通している.

鉄不動態皮膜のカソード還元に打ける皮膜外層の還元

* 電気化学協会第 48 回大会にて一部発表.

** 東京工業大学工学部 (广152 東京都目黑区大岡山 2-12-1) Tokyo Institute of Technology, Faculty of Engineering (2-12-1, O-okayama, Meguro-ku, Tokyo 152)

*** 現在, 新门本製鉄 (株) 第一技術研究所（广211 川崎市中 原区井田 1618)Present address : Nippon Steel Corporation, R \&D Lab.-I (1618, Ida, Nakahara-ku, Kawasaki 211)

Key Words: Passire Film, Cathodic Reduction, Resistometry, Passivity of Iron
機構については，多くの研究者により 3 価の鉄酸化物ま たは水酸化物がほぼ $100 \%$ の電流効率で 2 価の鉄イオン に還元溶解することが確認されている.しかしながら皮 膜内層の還元反応機構については多くの説が提唱されて いるが，それらはいずれも理論的に十分な解析がなされ ているとは言い難い。

Nagayama と Cohen ${ }^{1,2)}$ は，鉄不動態皮膜の定電流還 元におけるクロノポテンシォメトリーと，その際溶出す る 2 価の鉄イオンの比色分析の結果から, $\mathrm{Fe}_{3} \mathrm{O}_{4}+8 \mathrm{H}^{+}$ $+8 \mathrm{e} \rightarrow 3 \mathrm{Fe}+4 \mathrm{H}_{2} \mathrm{O}$ なる 反応が $30 \sim 40 \%$ の電流効率 で進行すると考えた，西村, 工藤, 佐藤は ${ }^{4)}$, 比較的低 い電流密度で溶液を頻繁に交換しながら不動態皮膜を定 電流還元し, 溶出した 2 価の鉄イオンを比色分析で定量 した. そして溶出してくる2 価の鉄イオンの量と通過電 気量との閒に比例関係があり，その保数が 3 価の鉄酸化 物が完全に還元溶解するとして計算したときの值と一致 したことから，内層の $r-\mathrm{Fe}_{2} \mathrm{O}_{3}$ がこの条件下では電流 効率 $100 \%$ で還元溶解すると考えた. Tsuru, Haruya$\mathrm{ma}^{6,7)}$ は, 鉄不動態皮膜構造注外層に $r-\mathrm{Fe}_{2} \mathrm{O}_{3}$ 内層に $\mathrm{Fe}_{3} \mathrm{O}_{4}$ である考え, 比色分析, クーロメトリー, レジ ストメトリーの結果加ら，皮膜内層の還元反応は $\mathrm{Fe}_{3} \mathrm{O}_{4}$ $+8 \mathrm{H}^{+}+z \mathrm{e} \rightarrow x \mathrm{Fe}^{2+}+y \mathrm{Fe}+4 \mathrm{H}_{2} \mathrm{O} \quad(x+y=3,2 x=8-$ z) で表わされ， $\mathrm{Fe}_{3} \mathrm{O}_{4}$ 層の一部は $\mathrm{Fe} に$ にまた一部は $\mathrm{Fe}^{2+}$ に還元されるものと考えた.さらに $x$ の值は $\mathrm{pH}$ に依存し, $\mathrm{pH}$ が 6.5 から 9.0 の間で $x=10.8-1.20$ $\mathrm{pH}$ といら実験式が成立することを示した。しかしなが ら $x$ の值が $\mathrm{pH}$ に依存する理由は示されていない。

このように，鉄不動態皮膜の解析は主としてカyード 
還元法に基づいているが，その還元機構，とくに不動態 皮膜内層の還元機構が不明確であるため, その還元条件 の遥いなどにより異なる結果が得られるものと考えられ る.

そこで，本報では不明な点が多かった不動態皮膜内層 の $\mathrm{Fe}_{3} \mathrm{O}_{4}$ のカソード還元機構について検討した.

\section{2 測定原理（レジストメトリー）}

レジストメトリーとは，薄膜電極のコンダクタンスの 変化の測定から固体電極の内部あるいは表面でおこる物 理的あるいは化学的変化に関する知見を得る方法であ $る^{8,7,13)}$. 本研究に関連する測定原理を簡単に述べる.

Fig. 1 に示寸酸化物に覆れた薄膜金属を電極として 用い，その両端の間のコンダクタンスを測定する.この

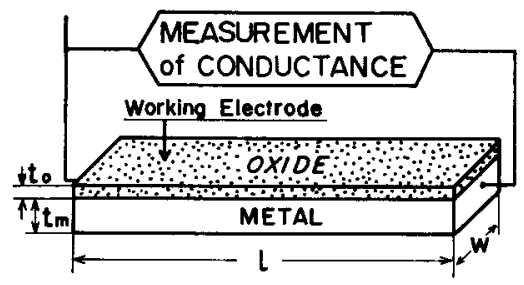

Fig. 1 Metal film electrode covered with oxide film for resistmetric study (schematic)

とき，電極長さを $l$, 幅を $w$, 金属層扝よび酸化物層の 厚さをそれぞれ $t_{\mathrm{m}}, t_{0}$ とする. 測定されるコンダクタ ンス $(K)$ は金属層㧍上ひ酸化物層のコンダクタンスの 和であるから，それぞれの比抵抗を $\sigma_{m} ， \sigma_{0}$ 上すると次 式が得られる.

$$
\begin{aligned}
K & =K_{0}+K_{\mathrm{m}} \\
& =\frac{w}{\sigma_{0} \cdot l} \cdot t_{0}+\frac{w}{\sigma_{\mathrm{m}} \cdot l} \cdot t_{\mathrm{m}}
\end{aligned}
$$

アノード酸化あるいはカソード還元により金属および酸 化物層の厚さが変化すると，コンダクタンスも変化す る.すなわち, コンダクタンスの変化量 $(\triangle K)$ は金属 層と酸化物層の厚さ变化量 $\left(\triangle t_{\mathrm{m}}, \triangle t_{0}\right)$ に対応している ことになる.

$$
\triangle K=\frac{w}{\sigma_{0} \cdot l} \triangle t_{0}+\frac{w}{\sigma_{\mathbf{m}} \cdot l} \Delta t_{\mathbf{m}}
$$

ここで次のカソード反応が起る場合の $\triangle K$ を考える.

$$
\begin{aligned}
& \mathrm{Me}_{x} \mathrm{O}+2 \mathrm{H}^{+}+z \mathrm{e} \rightarrow x \mathrm{Me}+\mathrm{H}_{2} \mathrm{O} \\
& \mathrm{Me}_{x} \mathrm{O}+2 \mathrm{H}^{+}+z \mathrm{e} \rightarrow x \mathrm{Me}\{(2-2) / x\}+ \\
& \mathrm{H}_{2} \mathrm{O}
\end{aligned}
$$

(3) 式に示す酸化物の金属一の還元が起るときは， $\triangle K$ は（5）式になり，(4) 式の酸化物の還元溶解では， $\Delta t_{\mathrm{m}}$ $=0$ より (6) 式となる.

$$
\begin{aligned}
& \triangle K=\frac{w}{z F l}\left(\frac{x M_{\mathrm{m}}}{\sigma_{\mathrm{m}} \cdot \rho_{\mathrm{m}}}-\frac{M_{0}}{\sigma_{0} \cdot \rho_{0}}\right) \cdot Q \\
& \triangle K=-\frac{w}{z F l} \cdot \frac{M_{0}}{\sigma_{0} \cdot \rho_{0}} \cdot \mathrm{Q}
\end{aligned}
$$

ここで， $M$ は酸化物の式量あるいは金属の原子量を表 わし, $\rho, F, Q$ はそれぞれ密度, ファラデー定数, 単位 面積あたりの通過電気量を表わす，一般には $\sigma_{\mathrm{m}} \ll \sigma_{0}$ の 関係が成立するから (5) 式の定数項は正の值をとり, 測 定される $\triangle K$ は $Q$ の増加记伴って増大する。また $\sigma_{0}$ が非常に大きな值をとる場合は (6) 式の定数項はほとん どゼロとみなすことができ，コンダクタンスはほぼ一定 の值を示し変化しない.

\section{3 実験方法}

試料には $99.9 \%$ 純鉄を用いた.レジストメトリー用 には，コンダクタンスの変化を鋭敏に測定できるよう に, ガラス基板上に純鉄を $6 \times 0.4$ (長さ $\times$ 幅) $\mathrm{cm}^{2}$, 厚さ 約 $500 \mathrm{~A}$ に真空蒸着した電極を使用し, また溶解イオ ンの比色分析用には圧延した純鉄を表面積が $10 \mathrm{~cm}^{2}$ に なるように短冊状に切り出したものを使用した. 蒸着膜 電極注 $600^{\circ} \mathrm{C}$ で 1 時間, 短冊状電極は $800^{\circ} \mathrm{C}$ で 4 時間 水素気流中で焼鈍省行った. 短冊状電極は Nagayama, Cohen ${ }^{1,2\rangle}$ と同様の方法で電解研摩を施した.

コンダクタンス変化の測定は, ホイートストンブリッ ヂに $1000 \mathrm{~Hz}$ の微小な交流信号をかけ，そのとき得ら れる非平衡電圧を增幅し，その出力をペンレコーダーで 連続記録することにより行った。

電解液は， $0.15 \mathrm{M}$ のホウ酸と $0.15 \mathrm{M}$ のホウ酸ナ卜 リウム溶液を混合して所定の $\mathrm{pH}$ に調整した楥衝溶液 を, 精製窒素ガスにより 48 時間以上脱気して実験に供 した. 実験はすべて空素ふん囲気中で行った。

また，セル中に窒素ガスバブラーをセットし，必要に 応じて電解液のかくはんを行った。

溶出した鉄イオンは，ピリジルアゾレゾルシンを発色 鼡として吸光分析により定量した ${ }^{15}$. 測定感度は吸光度 0.01 に対して $0.0174 \mathrm{ppm}$ ある。照合極注飽和カロメ ル電極を使用した。

\section{4 結果と考案}

\section{1 鉄不動態皮膜のカソード遇元反応}

$0.5 \mathrm{~V}$ で不動態化した純鉄の蒸着膜を溶液のかくはん なしの状態で $20 \mu \mathrm{A} / \mathrm{cm}^{2}$ の定電流で還元すると, Fig. 2 に示すレジストメトリーカーブ（電位 $E$ およびコンダ クタンス変化量 $\Delta K$ を通過電気量に対してプロットし たもの）が得られる. 図より、レジストメトリーカーブ は次の 3 領域に分けられることがわかる.まず，電位が 最初の停滞を示す「第I領域」では，(7) 式の反応が ほぼ $100 \%$ の電流効率で起こっていると報告されてお $\eta^{1,2,6,7,9)}$, この領域でコンダクタンスの変化が見られ $r-\mathrm{Fe}_{2} \mathrm{O}_{3}+6 \mathrm{H}^{+}+2 \mathrm{e} \rightarrow 2 \mathrm{Fe}^{2+}+3 \mathrm{H}_{2} \mathrm{O}$

ないことから，外層を形成している $r-\mathrm{Fe}_{2} \mathrm{O}_{3}$ の比抵抗 が金属の鉄に比べ相当大きいことがわかる．この領域の 
初期におけるコンダクタンスの急上昇は，不動態皮膜表 面に吸着した酸素のカソード還元に伴らものと考えられ ており，不動態皮膜外層の半導体特性と関連があること が指摘されているが娄, 理論的な解析はまだなされてい ない.

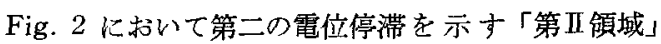

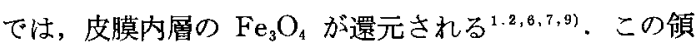
域では，コンダクタンス変化が大きく，しかも直線的に 増加していることから，少くともある割合で $\mathrm{Fe}_{3} \mathrm{O}_{4}$ か ら電気伝導度の大きい $\mathrm{Fe}$ 八の還元がおこっていること がわかる. 一方, 比色分析の結果からは, この領域でも 2 価の鉄イオンの溶出む起きていることが確認されてい $る^{4,6)}$.

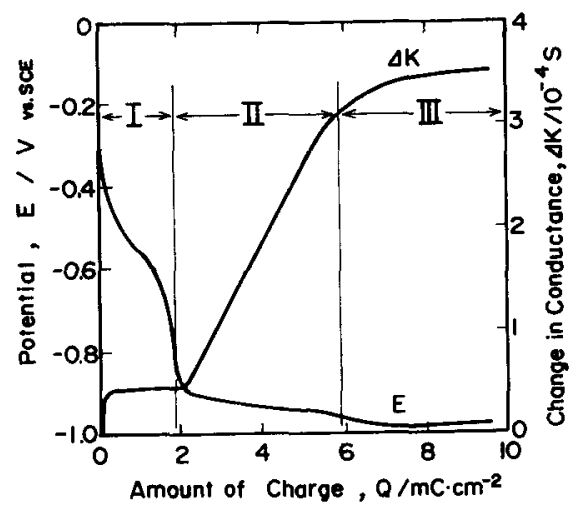

Fig. 2 Typical change in potential and conductance of passivated iron during galvanostatic reduction at $20 \mu \mathrm{A} / \mathrm{cm}^{2}$ as passivated at $0.5 \mathrm{~V}(v s . \mathrm{SCE})$

最後の電位停滞を示す「第正領域」では，鉄の裸の面 で水素発生が括きておう，コンダクタンス注ほぼ一定值 をとる。

\section{2 鉄不動態皮膜内㸴のカソード還元}

第开領域に扔ける主反応は, Tsuru, Haruyama ${ }^{6)}$ に よると (8) 式で示され，2 価の鉄イオンの溶出割合, す なわち $x$ の值は $\mathrm{pH}$ が低くなるほど増大することが報告 されている.

$$
\begin{aligned}
\mathrm{Fe}_{3} \mathrm{O}_{4} & +8 \mathrm{H}^{+}+(8-2 x) \mathbf{e} \\
\rightarrow & \rightarrow x \mathrm{Fe}^{2+}+(3-x) \mathrm{Fe}+4 \mathrm{H}_{2} \mathrm{O}
\end{aligned}
$$

また，回転リング・ディスク電極 (RRDE) 不動態化した鉄ディスク電極を定電流畺元し，溶出する 鉄イオンをリング電極で電流として同時測定すると， $x$ の值はやはり同様の $\mathrm{pH}$ 依存性を示すことが報告されて いるッ. しかしながら同じ $\mathrm{pH}$ の溶液中で還元した場合 でも RRDE とよりかくはん状態で行ったときの $x$ の值 は，かくはんなしのときのものより大きな值をとってい る.

溶液のかくはんと $x$ の值との間連性を検討するため
に, セル中の電解液を精製窒素ガスの気泡によりかくは んし，その条件下でレジストメトリーによる測定を行っ て, 皮膜内層の $\mathrm{Fe}_{3} \mathrm{O}_{4}$ の還元反応機構を解析した. 氻 くはんの程度はセル排気系にセットした流量計で窒素ガ スの流量を調節し，どの場合も一定となるように制御し た.

Fig. 3 は, 鉄蒸着膜電極を $\mathrm{pH} 8.39$ の電解液中で $0.5 \mathrm{~V}, 1$ 時間定電位酸化して不動態化させた後, 電流密 度 $20 \mu \mathrm{A} / \mathrm{cm}^{2}$ で定電流還元したときのレジストメトリ 一カーブで, 破線はかくはんなしの状態, 実線はかくは

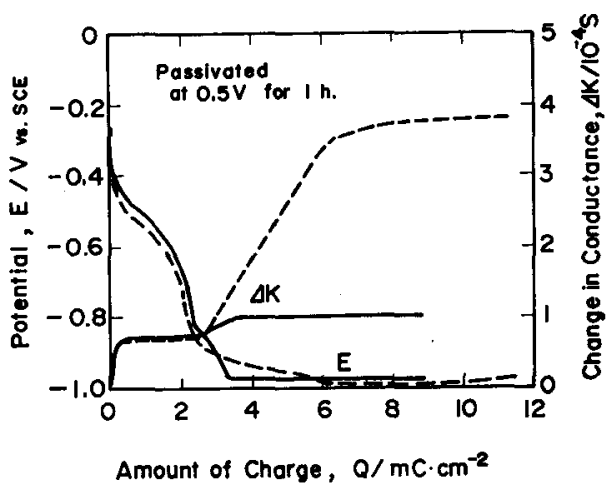

Fig. 3 Change in potential and conductance of passivated iron film electrode during gaIvanostatic reduction c. d. $=20 \mu \mathrm{A} / \mathrm{cm}^{2}$, as passivated at $0.5 \mathrm{~V}$ (vs. SCE) for 1 hour

-. - : Without convection, _- : Under convection

ん状態のものである.この図より，第Ｉ領域における電 位およびコンダクタンス変化は，かく江んに上りほとん ど影響を受けないことがわかる.一方，第領城化拉け る電位の停滞幅, 寸なわち電気量は, 溶液をかくはんす ると大幅に減少すること，またこの領域におけるコンダ クタンスの上昇率がかくはんによりかくはんしない場合 に比べてきわめて小さくなることがわかる．これらの現 象は，かくはんにより $\mathrm{Fe}_{3} \mathrm{O}_{4}$ から 2 価の鉄イオンとして 還元溶解する割合が堌大した，すなわち (8) 式の $x$ の值 が増大したことによるとして説明でき，前述の RRDE の結果乹とも一致する.

\section{3 飽和層形成による鉄（II）イオンの拡散}

前節までの結果から， $\mathrm{Fe}_{3} \mathrm{O}_{4}$ の還元反応は（8）式に 徉い，pH の低下拉上び溶液の汃くはんより式中の $x$ の值が増加することがわかった。すなわち，この現象に はカソード還元生成物である 2 価の鉄イオンの飽和濃度 ならびにその搪散速度が関倸しているものと考えられ る.

Misawa の熱力学的デーダ によれば， $\mathrm{pH}$ 8 11の 範囲では，2 価の鉄イオンはそのほとんどが $\mathrm{FeOH}^{+}$と 
して存在するとされている.また $\mathrm{FeOH}^{+}$と $\mathrm{OH}^{-}$との 溶解度積が $10^{-9.4}$ であることから, $\mathrm{FeOH}^{+}$の飽和浱度 $C^{\text {sat }}\left(\mathrm{FeOH}^{+}\right)$は,

$$
C^{\mathrm{sat}}\left(\mathrm{FeOH}^{+}\right)=10^{4.63-\mathrm{pH}}
$$

で表わされ，中性溶液ではきわめて小さい，このことか ら, $\mathrm{Fe}_{3} \mathrm{O}_{4}$ の還元溶解反店は電極表面に形成される 2 洒 の鉄イオンの飽和層により支配されていることが予想さ れる.

そこで（8）式を（10）式および（11）式のように分割 し, 還元溶解反応と $\mathrm{FeOH}^{+}$の飽和濃度との関連性を以 下に検討する。な㧍， $\mathrm{Fe}_{3} \mathrm{O}_{4}$ の $\mathrm{Fe}$ への還元反応は，お そらく $\mathrm{Fe}_{3} \mathrm{O}_{4}$ から還元溶出した 2 洒の鉄イオンが金 属 鉄に還儿析出するものと考元られるが，ここでは後の解 析を単純化するために (10)，(11）式の並列反応として処 理する*1。

$$
\begin{aligned}
& \mathrm{Fe}_{3} \mathrm{O}_{4}+8 \mathrm{H}^{+}+8 \mathrm{e} \rightarrow 3 \mathrm{Fe}+4 \mathrm{H}_{2} \mathrm{O}, i_{1} \\
& \mathrm{Fe}_{3} \mathrm{O}_{4}+5 \mathrm{H}^{+}+2 \mathrm{e} \rightarrow 3 \mathrm{FeOH}^{+}+\mathrm{H}_{2} \mathrm{O}, i_{2}
\end{aligned}
$$

ここで， $i_{1} ， i_{2}$ は (10)，(11) 式を並列反応と考光たとき のそれぞれの反応する電流密度である．Fig. 4 に (11) 式の反応が進行しているときの $\mathrm{FeOH}^{+}$の濃度分布を模 式的に示す.かくはんなしの状態に㧍いて Nernst 近似 による搪散層厚さ $\delta$ は， $\delta \approx 0.05 \mathrm{~cm}$ の值をとることが 知られている ${ }^{14}$ 。この厚さを図中纪 $\delta_{\mathrm{s}}$ で示した。 た溶液の $\mathrm{pH}$ から (9) 式によって $\mathrm{FeOH}^{+}$の飽和濃度 が決まり， $\mathrm{FeOH}^{+}$の濃度こう配に対応する電流值は， 反応（11）の昖散限界電流である. それゆえ，この限界 電流より大きい電流值でカソード還元を行らと残りの電 流は（10）式の反応に費やされることになる。ここで, 溶液をかくはんすると拡散層厚さが薄くなり， $\delta \mathrm{c}$ とい う㥀をとる。すると濃度こう配の最大值はかくはんのな

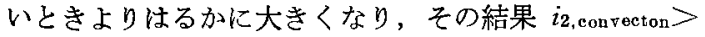

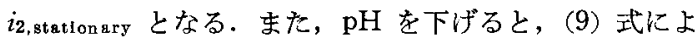
り $\mathrm{FeOH}^{+}$の飽和濃度が增加し, $\mathrm{pH}$ の高い場合上り大き

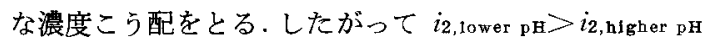
となる. 以上より, 定電流還元における $i_{1}$ と $i_{2}$ の割合 が $\mathrm{pH}$ やかくはん条件によって変化することが定性的に 理解される.

次に，(8) 式に扝讨る $x$ の值の $\mathrm{pH}$ ，拡散層厚さ，掠 よび還元電流密度依存性を上に述べた 1 価の鉄イオンの 電極表面飽和モデルを用いて計算する. 第領域では水 素発生反応が並行反応として起きている可能性があるの で，鉄酸化物のカソード還元の電流効率を $\xi$ と寸ると， 全電流密度 $i_{\text {total }}$ と $i_{1}, i_{2}$ との関係は次式であらわされ る.

\footnotetext{
*1 実際の反心過程は, $\mathrm{Fe}_{3} \mathrm{O}_{4}+5 \mathrm{H}^{+}+2 \mathrm{e} \rightarrow 3 \mathrm{FeOH}^{+}{ }_{\mathrm{s}}+\mathrm{H}_{2} \mathrm{O}$ $\left\{\begin{array}{l}\mathrm{FeOH}^{+}{ }_{\mathrm{s}}+\mathrm{H}^{+}+2 \mathrm{e} \rightarrow \mathrm{Fe}+\mathrm{H}_{2} \mathrm{O} \\ \mathrm{FeOH}^{+}{ }_{\mathrm{s}} \stackrel{\text { difuse }}{\longrightarrow} \mathrm{FeOH}^{+}{ }_{\text {bulk }} \text { で活るる }\end{array}\right.$
} 思われる（添字 $\mathrm{s}$ は表面を意味する）。

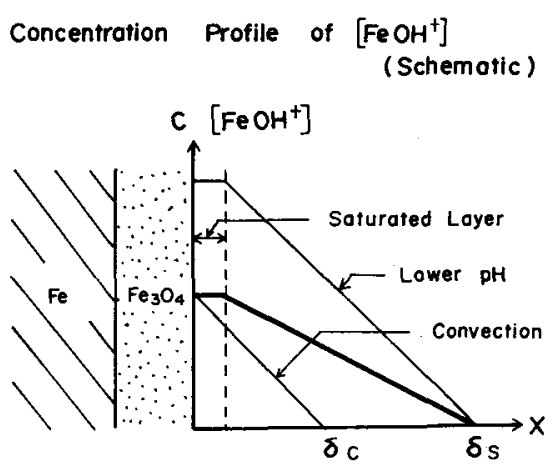

Reductive Dissolution Rate, i2:

$$
\begin{aligned}
& 12, \text { convection } \\
& i 2, \text { lower } \mathrm{pH}>\mathrm{i} 2 \text {, stotionary }
\end{aligned}
$$

Fig. 4 Scheme for reductive dissolution of $\mathrm{Fe}_{3} \mathrm{O}_{4}$ (inner layer of passive film on iron)

$$
i_{1}+i_{2}=\xi \cdot i_{\text {total }}
$$

2 価の鉄イオンの飽和濃度 $C^{\mathrm{sat}}(\mathrm{Fe}(\mathrm{II}))$ は, $\mathrm{Fe}^{2+}$ と $\mathrm{FeOH}^{+}$の飽和濃度 $\mathrm{C}^{\text {sat }}\left(\mathrm{Fe}^{2+}\right), \mathrm{C}^{\text {sat }}\left(\mathrm{FeOH}^{+}\right)$の和で 表わされるので, Misawa の熱力学的データ ${ }^{8)}$ より次式 が得られる。

$$
\begin{aligned}
C^{\text {sat }}(\mathrm{Fe}(\mathrm{II}))= & \mathrm{C}^{\mathrm{sat}}\left(\mathrm{Fe}^{2+}\right)+\mathrm{C}^{\mathrm{sat}}\left(\mathrm{FeOH}^{+}\right) \\
= & \left(10^{11.36-2 \cdot \mathrm{pH}}+10^{4.63-\mathrm{pH}}\right) \times 10^{-3} \\
& \left(\mathrm{~mol} \cdot \mathrm{cm}^{-3}\right) \quad(13)
\end{aligned}
$$

$i_{2}$ 法（8）式の $x$ を用いることにより次のよ5に表わさ れる.

$$
i_{2}=\frac{x}{12-3 x} \cdot \xi \cdot i_{\text {total }}
$$

Fick の第一法則より

$$
i_{2}=\frac{2}{3} F D\left(\frac{\partial C}{\partial x}\right)_{x=0} \simeq \frac{2}{3} F D \frac{C^{\mathrm{sat}}(\mathrm{Fe}(\mathbb{I I}))}{\delta}
$$

ここで，Dは 2 価の鉄イオンの桩散定数である．いま， (11) 式の反応がその限界電流密度で進行するものとし て（14）式と（15）式を連立させ， $i_{2}$ を消去し $x$ につい で整理すると次式が得られる。

$$
x=\frac{8 F D C^{\mathrm{sat}}(\mathrm{Fe}(\text { II }))}{\delta \cdot \xi \cdot i_{\text {total }}+2 F D C^{\mathrm{sat}}(\mathrm{Fe}(\text { II }))}
$$

この式より，電流効率 $\xi(0 \leq \xi \leq 1)$ がわかれれ゙ $x$ の值の $\mathrm{pH}, \delta$ 扔よび $i_{\text {total }}$ 依存性が計算できる.

\section{4 表面飽和層モデルの検討}

$\mathrm{Fe}_{3} \mathrm{O}_{4}$ 層のカソード還元の際に, 2 価の鉄イオンが電 極表面で飽和していると仮定し解析を行ってきたが，こ の妥当性を検討するために理論值と実験値とを比較す る. 実験データからxの值を求める方法は以下に記す通 りである。

第領域に拉けるコンダタタンス上昇率を $a\left(\mathrm{~S} \mathrm{~cm}^{2} /\right.$ $\mathrm{mC})^{* 2}$ とすると（5) 式を導出したときと同様の考え 
方を(8)，(10),(11) 式に適用して式をたて， $\Delta K$ を $Q$ で微分することにより $a$ が求まる. その式を $x$ および $\mathrm{Fe}_{3} \mathrm{O}_{4}$ の比抵抗 $\sigma_{\text {mag }}$ について整理すると (19) (20) 式を得る.

$$
\begin{gathered}
x=\frac{4 \frac{a}{\xi}-\frac{w}{2 l F}\left(\frac{3 M_{\mathrm{Fe}}}{\sigma_{\mathrm{Fe}} \rho_{\mathrm{Fe}}}-\frac{M_{\mathrm{mag}}}{\sigma_{\mathrm{mag}} \cdot \rho_{\mathrm{mag}}}\right)}{\frac{a}{\xi}-\frac{w}{2 l F} \cdot \frac{M_{\mathrm{Fe}}}{\sigma_{\mathrm{Fe}} \rho_{\mathrm{Fe}}}} \\
\left.\sigma_{\mathrm{mag}}=\frac{w M_{\mathrm{mag}} / 2 l F \rho_{\mathrm{mag}}}{\left(\frac{a}{\xi}-\frac{w \cdot M_{\mathrm{Fe}}}{2 l F}\right) x-\left(4 \frac{a}{\xi}-\frac{3 w M_{\mathrm{Fe}}}{2 l F \sigma_{\mathrm{Fe}}}\right)}\right)
\end{gathered}
$$

さらに, 電流効率 $\xi$ はターロメトリーにより求めること ができる.

$$
\xi=\frac{(4-x)\left(Q^{\mathrm{a}}-Q_{\mathrm{I}}^{\mathrm{e}}-2 Q_{1}^{\mathrm{sol}}\right)}{4 Q_{\mathrm{I}}^{\mathrm{c}}}
$$

ただし，添字の mag は $\mathrm{Fe}_{3} \mathrm{O}_{4}$ をあらわし， $Q_{\mathrm{a}}$ は不動 態皮膜形成に要するアノート酸化電気量, $Q_{1}^{\mathrm{c}}, Q_{\mathrm{II}}^{\mathrm{c}}$ はを

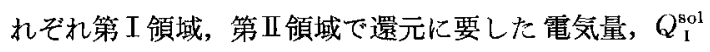
坆第工領域で還元溶出した 2 価の鉄イオンを電気量に換 算したものである。

これらの式により実験值と計算值の比較が可能にな る. 不動態化条件汶,すべての実験を通して $\mathrm{pH} 8.39$ の溶液中で $0.5 \mathrm{~V}(\mathrm{SCE}), 1$ 時間の定電位酸化とした. 比色分析の結果から, $\mathrm{pH} 8.39$, c.d $=20 \mu \mathrm{A} / \mathrm{cm}^{2}$, かく はんなしの状態で定電流還元を行ったところ， $x=0.7$ という值を得た.この值を用いて電流効率を(21) 式に より計算したところ, 蒸着膜電極では $\xi \simeq 0.5$, 比色分析 用矩冊型電極では $\xi \simeq 0.9$ という值が計算された. 電流 効率に差があるのは電極の表面粗度や触媒活性などによ るものと考えられるが，詳細は明らかではない，次に (20)式を用いて $\mathrm{Fe}_{3} \mathrm{O}_{4}$ の比抵抗を計算したところ, $\sigma_{\text {mag }} \simeq 3.2 \times 10^{-4}(\Omega \mathrm{cm})$ となり, Tsuru, Haruyama に よって計算された $2 \times 10^{-4}(\Omega \mathrm{cm})^{6)}$ とほぼ一致した。た だし（20）式中の各パラメータの值として， $M_{\operatorname{mag}}=$ $231.4, M_{\mathrm{Fe}}=55.8, \sigma_{\mathrm{Fe}}=9.8 \times 10^{-6} \Omega \mathrm{cm}, \rho_{\mathrm{Fe}}=7.86 \mathrm{~g} /$ $\mathrm{cm}^{3}, \rho_{\mathrm{mag}}=5.2 \mathrm{~g} / \mathrm{cm}^{3}, F=9.65 \times 10^{7} \mathrm{mC} / \mathrm{eq}, l=6.0 \mathrm{~cm}$, $w=0.4 \mathrm{~cm}$, そして $a$ としてはこの条件下で得られる平 均值 $0.8 \times 10^{-4} \mathrm{Scm}^{2} / \mathrm{mC}$ を用いた.

これで(19) 式における定数はすべて求まった。ささま ざまな条件下での $a$ を測定し, この式に代入することに より各条件下における $x$ の值を計算することができる.

また, 2 価の鉄イオンの拡散定数を， $D=5 \times 10^{-6} \mathrm{~cm}^{2} /$ $\sec ^{10)}$ とすれば，(13) (16) 式を用いて $x$ の理論值も計 算できることになる。

Fig. 5 に $x$ の值の還元電流樒度依存性を示す. 黑丸 は前述の手順で不動態化させた試料を同じ $\mathrm{pH} 8.39$ の

$$
*^{2} \mathrm{~S}=\Omega^{-1}
$$

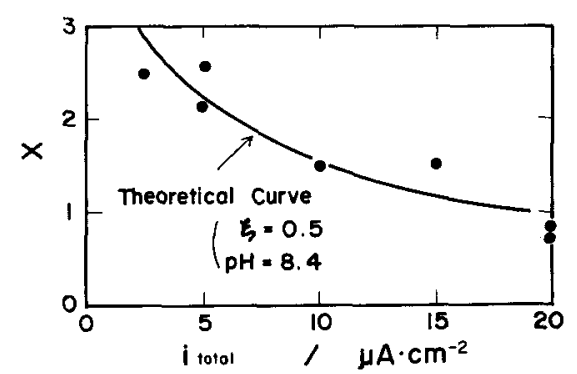

Fig. 5 Variation of $x$ with $i_{\text {total }}$ $x$ was estimated by resistmetric measurement with $\mathrm{pH} 8.39, \xi=0.5$ without convection

溶液中でさまざまな電流密度を用いて定電流還元したと き得られたレジストメトリーによる実験值で，実線は $\mathrm{pH} 8.4, \xi=0.5, \delta=0.05 \mathrm{~cm}^{14)}$ としたときの理論曲線 である.両者は非常によく一致しているが, このように 逼元電流密度の増加に伴い $x$ の值が小さくなるのは, $i_{2}$ の最大值が 2 価の鉄イオンの飽和濃度で決定されるの で, 全電流に占める $i_{2}$ の割合が減少するためである.

Fig. 6 は， $x$ の值の昖散層厚さ $\delta$ に対寸る依存性を $i_{\text {total }}=20 \mu \mathrm{A} / \mathrm{cm}^{2}, \xi=0.5$ として計算した曲線である.

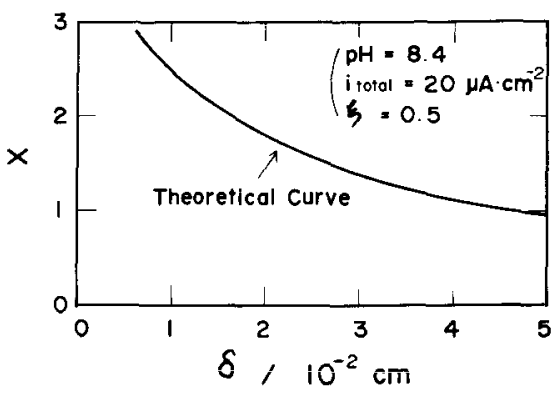

Fig. 6 Variation of $x$ with thickness of diffusion layer $(\delta)$

これまでのところ定量的な実験データは得られていない が，チャンネルフロー電極 ${ }^{16)}$ を用いたレジストメトリー による測定を検討している。この計算結果から，溶液中 に対流が生じ拡散層が薄くなると，xの值が增大寸るこ とがわかり，前述の RRDE の結果㧍よび Fig. 3 の結 果が理解される。

Fig. 7 は $x$ の值の $\mathrm{pH}$ 依存性を示したもので, 黒㚘 は不動態化した鉄をカyード電流密度 $20 \mu \mathrm{A} / \mathrm{cm}^{2}$ で還 元し, 溶液の比色分析により $x$ の值を求めたもので, 計 算には c.d. $\left.=20 \mu \mathrm{A} / \mathrm{cm}^{2}, \xi=0.9, \quad \delta=0.05^{14}\right) \mathrm{cm}$ を用い た. $\mathrm{pH} 7.4$ において $x$ の值が理論曲線からずれている が,これはこの $\mathrm{pH}$ における溶液の緩衝能が, $\mathrm{pH} 8.4$ 前後のときより低く, $\mathrm{Fe}_{3} \mathrm{O}_{4}$ の還元反応が水素イオン消 費型であることから電極表面近傍の $\mathrm{pH}$ が反店進行中に 若干上昇したために生じたものと思われる。 


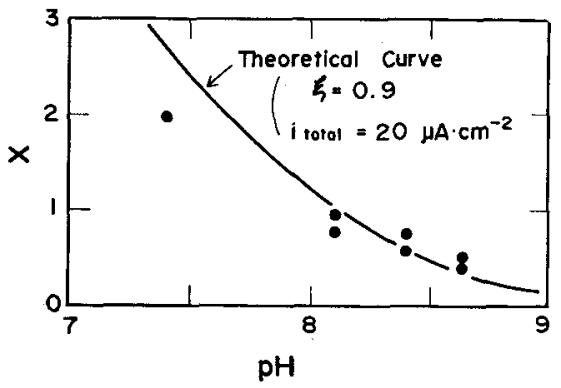

Fig. 7 Variation of $x$ with $\mathrm{pH}$ $x$ was estimated by colorimetric measurement with $i_{\text {total }}=20 \mu \mathrm{A} / \mathrm{cm}^{2}, \xi=0.9$ without convection

\section{5 結 論}

鉄不動態皮膜内層形成する $\mathrm{Fe}_{3} \mathrm{O}_{4}$ 層のカソード還 元反応を，(10)，(11）式の 2 つ立列反応と考え，(11) 式の還元溶解反忘は, 電極表面に㧍ける2 佂の鉄イオン の飽和層形成により，拡散で律速されると仮定した.

$$
\begin{aligned}
& \mathrm{Fe}_{3} \mathrm{O}_{4}+8 \mathrm{H}^{+}+8 \mathrm{e} \rightarrow 3 \mathrm{Fe}-4 \mathrm{H}_{2} \mathrm{O}, i_{1} \\
& \mathrm{Fe}_{3} \mathrm{O}_{4}+5 \mathrm{H}^{+}+2 \mathrm{e} \rightarrow 3 \mathrm{FeOH}^{+}+\mathrm{H}_{2} \mathrm{O}, i_{2}
\end{aligned}
$$

これにより， $\mathrm{Fe}_{3} \mathrm{O}_{4}$ から $\mathrm{Fe}$ と 2 洒の鉄イオンとに還元 される割合がカソード電流密度, 溶液の対流, $\mathrm{pH}$ によ って変化することが定量的に説明できた。

これまで鉄不動態皮膜内層の還元反応については，多 くの研究者によってさまざまな反応機構が提晿されてき

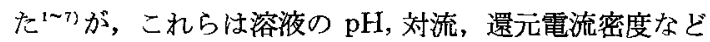
の奏験条件がそれぞれ異なっていたことから生じたもの と考えられ，本報のように 2 価の鉄イオンが電極表面に 飽和層を形成することを考慮すると，それらの相反する 内層の還元機構む理解できるものと思われる。

$$
\text { 文献 }
$$

1) M. Nagayama, M. Cohen, J. Electrochem. Soc. 109, 781 (1962).

2) M. Nagayama, M. Cohen, J. Electrochem. Soc. 110 , 670 (1963).

3）野田哲二, 工藤清勝，传藤教男，日本金属学会誌 37, 151 (1973).

4) 西村六郎, 工藤清勝, 佐藤教男, 電気化学 44, 198 (1976).

5) 估藤教男, 電気化学 46, 584 (1978).

6) T. Tsuru, S. Haruyama, Corros. Sci. 16, 623 (1976).

7) Haruyama, T. Tsuru, "Passivity and It's Breakdown on Iron and Iron Based Alloys, USA-Japan Seminer", p. 41 (1976), N.A.C.E.

8) T. Misawa, Corros. Sci. 13, 659 (1973).

9) 藤井栄一郎, 水流 徹, 春山志郎, 投稿準備中.

10) D.T. Chin, J. Electrochem. Soc. 121, 527 (1974).

11）東京天文台編，“理科年表”, 1974.

12）飯由修一編，“物理定数表”，朝倉書占，1969.

13）春山志郎, 水流 徹, 日本金属学会誌 $20 ， 643$ (1981).

14) J.O'M. Bockris \& A.N. Reddy, "Modern Electrochemistry", Vol. 2, p.1058, Plenum Press, 1969.

15）武内次夫, 四条好雄, 分析化学 14, 930 (1930).

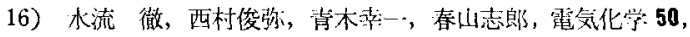
712 (1982).

(Received Feb. 7, 1984 ; Accepted Apr. 19, 1984)

お知方世

\section{昭和 59 年度金属材料技術研究所研究発表会}

\section{日 時: 11 月 6 日 (火) $13: 30 \sim 16: 40$ \\ 会 場：金属村料技術研究所大会議室}

（東京都目黒区中目黒 2-3-12）
1. 新し以超電導化合物線材
2. 磁気冷凍材料

3. 表面析出現象を利用した被覆法吉原一絋

4. 高圧液体噴霧法による合金の超微粉化武田徹 (O)問合先 153 東京都目黑区中目黒 2-3-12 金属材料技術研 究所企画課 (\&03-719-2271) 聴講無料.

\section{本誌の会告原稿について}

1. 原稿用紙：本誌の会告原稿は，本会会告用原稿用紙（横書 $28 \times 15$ 字行）を抢使い下さい.その他の原稿用紙の場合は, こ れに準して必ず1行を 28 字詰として使用のこと.

2. 締切期日：会告原稿の縍切日は提載月の前々月の 25 日(例10月号揭載 $\rightarrow 8$ 月 25 日締切・必着) となります.

3. 書き方 : 会告原稿の書き方は，扔手数でも本誌の会告記事に必ず淮拠願います.

4. 原稿用紙請求, 原稿送付先：干100 東京都千代田区有楽町 1-12-1 新有楽町ビル 電気化学協会会告保 